\title{
The Effect of Architecture Style on The Housing Thermal Condition in Humid Tropical Area
}

\author{
Feriza Nadiar ${ }^{1}$, I Gusti Ngurah Antaryama ${ }^{2}$, and Ima Defiana ${ }^{2}$
}

\begin{abstract}
Modern minimalist, Mediterranean and Modern tropical style are commonly found architecture styles in residences in Surabaya in the past decade. However, it is ironic that most of the styles are imported products which have different response level towards the local climate due to the fact that they are not designed for humid tropical areas. Thus, the choice of style has become really important so that the building can respond well to climate. This research was conducted on three architecture styles with three variants of each in a residential area in East Surabaya. This paper evaluates thermal performances and the influence of envelope elements on the thermal conditions in each sample house and evaluates which style that is potentially applicable to the humid tropical climate by using simulation method with the assistance of ECOTECT software. The results show that the variant $B$ of modern minimalist style has the best envelope performance. Overall, house envelope with the original design is not effective enough. Design modification with good and suitable elements for the B variant of the Modern minimalist and Mediterranean turn out to be resulting in a more effective in solving thermal problems.
\end{abstract}

Keywords - thermal performance, architecture style, houses, building envelope.

\section{INTRODUCTION}

In the last decade, environmental issues are often discussed in various disciplines and construction sector gave a relatively large negative impact on the global issues of the environment. Therefore, in the Conference Agenda 21, the designers were challenged to solve the problem in six themes or categories, one of which is to manage the human settlements by providing opportunities to the earth through the application of the principles of sustainable development, where economic development does not sacrifice social development and environmental life [1]. In response to the global issues regarding the environment and also the results of the conferences that have been held, Indonesia as a developing country and is building, already has a blueprint for the construction sector as a grand design and grand strategy called "Construction Indonesia 2030". And the construction of Indonesia should be oriented to not contribute to environmental degradation but instead became a pioneer repair and improvement of environmental quality across Indonesia habitat, which is inhabited by humans and all other beings are symbiotic mutualism [2].

Talking about Indonesian architecture, Indonesia is now more widely available foreign architectural form of the archipelago or traditional architecture [3]. It is caused by several factors, ranging from the environment to the teaching and learning architecture that dominates the mass media as the first gate. The mass media give treats many

${ }^{1}$ Feriza Nadiar, Departement of Environmental Architecture, Institu Teknologi Sepuluh Nopember, Surabaya, 60111, Indonesia. E-mail: ferizanadiar@yahoo.com of the western lifestyle, architecture, drawings and photographs entice the general public to emulate, not least by the architect. Therefore, the Indonesian people are more affected to practice motifs foreign architecture on the architecture of the country to be applied to the building without thinking that in fact not all conform applied in Indonesia because Indonesia is different climates with the climate abroad. Thus the new issues arise regarding the performance of modern buildings to the local climate, especially thermal problems.

Each architecture style has distinctive characteristics and its own uniqueness which can be identified from the building envelope. Thus, this research is focused on the building envelope including the building façade which becomes the face of a certain style. The main function of a building envelope is to filter the environmental conditions outside the building in relation to thermal issues in both passive and active ways [4]. In designing a building envelope, there are contradictions between the ways it is applied to a style without reducing the building performance in response to heat. Each style has a different material composition, surface, colour, and shape, so that its heating potential is different as well. The variables related to thermal performance in the envelope include walls and opening, roof, shades and ornaments.

The factors that require attention in evaluating the performance of building thermal, which include the temperature per hour to identify the time and duration of comfort and the percent dissatisfaction, then the degree hours to find out the thermal accumulation which reaches the standard threshold of comfortable temperature in 24 hours [5]. These aspects are then cross-checked with the standard in the humid tropical climate area to find the standard of determination so that it can later on be examined and evaluated in accordance with the housing standard of comfort in the humid tropical climate area.

\section{METHOD}

The simulation is done by using ECOTECT software. Before the simulation, measurements are conducted in relation with the thermal conditions towards A variants of the three styles which represent the original style. Field measurement is used to process the data verification. When the simulation process is being conducted, some simplification is done to the modeling.

Subjects to be studied is the style of the building envelope, and the selected object is a residential houses in Surabaya. In this study, more focussed on envelopeforming element as a typical to an each style. Object under study has the following criteria :

a. Location of residential houses located in Surabaya.

${ }^{2}$ I Gusti Ngurah Antaryama and Ima Defiana are with Department of Architecture, Institut Teknologi Sepuluh Nopember, Surabaya, 60111, Indonesia. E-mail: antaryama@ arch.its.ac.id, may.d@arch.its.ac.id. 
b. Surabaya city chosen because it includes one of the areas that are in the humid tropical climate and including urban areas where the temperature is high enough and there are houses with all three styles are studied.

c. Based on the typology of residential building in Surabaya, the kind that will be studied are row house. Type of residential building or home unit is attached to the right or left side of the building.

d. Based on the style to be studied, modern minimalist style that is most often found in housing projects Surabaya, while the Mediterranean style and modern tropical also be found in certain housing projects mainly middle to upper housing. In order to examine the house with the third style, the selected housing is middle to upper housing with total area of $100 \mathrm{~m} 2$ to $200 \mathrm{~m} 2$ and a building area of $200 \mathrm{~m} 2$ to $400 \mathrm{~m} 2$. Housing upper middle potential houses are built with the third style because the owners financial have enough funds to renovate or build a house in accordance with the existing style trends [6].

The sample selection using purposive sampling, sampling intentionally as per the requirements (the nature, characteristics, traits, criteria) and in accordance with the purpose of research [7]. Samples are carefully selected so that relevant to the study design. The method makes it easy to choose and eliminate that the sample becomes more conical. Understanding is intended to sample selected is in accordance with the specifications of the study. Selection of the population which is the object of study in this research is based on a review typology of residential buildings and is based on a style that is widely used in the area of Surabaya. The population and the sample is selected based on criteria that have been mentioned. Selection of the appropriate population criterion that upper and middle housing in Surabaya. Based on the results of previous studies on the attributes of architectural design, housing in east and west Surabaya got a lot of appreciation for designs that follow the trends and can even design their own will. Overall, the pattern of the population and the determination of the sample described in Figure 1.

Determination of variants based on the characteristics and key elements that must be present and describe the style [8]. The following features and elements that must exist in every style (Table 1)

With the enactment of the main criteria above, the percentage of the elements mentioned above become the main and largest percentage, while other elements are variations of elements that percentage is not the main criteria. Here the percentage of each element in each style (Table 2)

Based on the percentage distribution of elements conformity with the original style of the above, the following provisions of the distribution of variants of each style:

a. Each style is divided into three variants. A, B, and C.

b. Variant A has a percentage of $85-100 \%$ match traits with the literature.

c. Variant B has a percentage of $75-85 \%$ match traits with the literature.

d. Variant B has a percentage of 70-75\% match traits with the literature. (minimum 1 match with the main criteria)
Figures obtained from the percentage of suitability aspects of the roof, walls and openings, ornaments and sun shading on each style.

In a collection of a few houses with one particular style, taken three houses that represent each variant. Determining the sample at each variant is done by using the table below (Table 3)

In the table above, of the existing house (one particular style), weighting is done to take each one home to one variant.

From the classification above, house are taken as samples for each style with its variants is in Table 4.

\section{A. Equality Comparison}

Data on building volume of 9 houses the research samples are very diverse. To achieve the ultimate goal of this research is by doing comparisons across nine samples of the house, a ratio of one house to another must be balanced to enable the equality comparison. Data volumes are different in each building will not be compared with each other because the resulting effect on the performance and process simulation. Therefore, simplification of the sample house has an area over $1000 \mathrm{~m} 2$. Simplification is done by eliminating secondary chambers so that the only remaining primary room with an area which is not much difference with the others. The range extents will be compared in this study is $630-900 \mathrm{~m} 3$ with $10-12$ m wide facade. The following is the modeling of the nine sample houses. (Table 5)

\section{RESULTS AND DISCUSSION}

Simulation 9 buildings which of the three styles with each of the three variants of each style will be compared in accordance with the analysis that has been done on the thermal conditions in the building. The comparison is intended to be able to identify the condition and performance of the best and worst, and in accordance with the humid tropical climate.

\section{A. Performance and Thermal Comfort Entire Household Sample}

Analysis of the results obtained based on the temperature conditions of temperature profile data for each hour of each style and its variants were then analyzed regarding:

1) Thermal comfort level (time and duration comfortable)

The temperature profile simulation result is different from the temperature profiles obtained from field data. The temperature profile in the data field consists of only 2 data, the temperature inside the building and outside temperature. This is due to the limitations of the tool so that the measurement is only carried out at two points to represent each condition that is a point in space in the building close to the envelope, one point again outside the building. While the simulation results of more complex data that temperature throughout the room in the building. Analysis time and duration comfortable can be seen on the temperature profile of the simulation results that can determine favorable conditions a function of time. 
2) Degree hours

Degree hours are accumulated value obtained from the difference between the temperature (inside / outside) space with a temperature threshold above the comfort zone for 24 hours [12].

3) Percent dissatisfaction

Analysis percent satisfaction obtained from the simulation results percent dissatisfaction with the contour color output. Percent satisfaction analysis aims to determine what percentage of zones in the building that does not meet the standards that meet the standards of comfort and discomfort. The percentages indicate the performance of the building, especially the envelope in creating thermal comfort inside the building in accordance with the standards of comfort in the humid tropical climate.

The overall simulation results can be seen in the table and the following Table 6 and Figure 2.

B. Elemental Breakdown Regard to Side Envelope and Material Thermal Properties on the Entire Sample Houses

The following data from the entire simulation on the hottest envelope side in the entire sample home (Table 7) and its constituent elements (Table 8)

Qs + Qv value analysis resulted in the identification of the side of the envelope which became potential in contributing to the heat into the building. In the side of a envelope itself is inseparable from the elements that compose it and the elements of its own can not be separated from the material which it is composed.

Can be seen in the table above that the constituent elements on envelope side which accounts for the highest heat was dominated by a mix of elements that form the walls and large-fixed window openings. The combination elements of walls and garage doors are also the same as the mix wall and large-fixed window openings and occupies the second position. This is due to a mix of elements of walls and garage doors are also very minimal ventilation resulting in increased heat.

At the constituent elements of the envelope side which accounted for the lowest heat also exist that dominates, which is a combination of elements walls, windows, doors, and sun shading. The combination of these elements are found in 5 of the 9 samples house. This means the sun shading element is very helpful to reduce the heat that enters the building. After that, mix elements of proportional walls and openings are ranks second. Openings with function and the correct size can provide air circulation and wind can ease the heat in the building.

After the element, then breakdown again any material used in the elements and the results have been presented in the discussion of the relationship and its performance with design elements.

In the previous discussion, the elements were identified as the dominant element which accounts for the highest heat is a combination of elements that the walls and largefixed window openings. At the time of this analysis, the dominant material constituting the element is the material of bricks and plaster as the wall material and single glass and aluminum frame. In the discussion of material properties in each style, single glass material and aluminum frame has been touted as a potential material in an increase in heat and turns the simulation results obtained similar results. While the elements were identified as the dominant element which accounts for the lowest heat is a combination of elements of walls, windows, doors and sun shading. The combination of these elements forms an envelope in the form of a terrace or balcony canopy in the middle of the building and it is typical of the Mediterranean style at first. The most effective material for the envelope of sun shading particular elements are brick, plaster and paint layers such as wall material and canopy like in the original Mediterranean style. Canopy with other materials, such as fiber and also have a small area that is less able to reduce heat entering.

\section{Relationship of Performance and Comfortable with Envelope Design}

From the simulation results on the performance and comfort then compared with the design and envelope elements to answer the question how the design affected to the thermal conditions in buildings. The following comparisons were made:

\section{1) Relationship Performance and Comfort by Design} Roofing

The relationship of performance and comfort with the roof design is shown in the following graph (Figure 3). When referring to the tropics home theory outlined above, the analysis of the thermal performance relationship with the roof design is appropriate. Previously described that is identical to the tropical house is a roof house (wide roofed with wide eaves anyway). In the simulation results also showed similar results. Roof design has the best performance is the design of a typical tropical roof with wide eaves. And according to the theory and the simulation results we can conclude that for a modern tropical house can be used any material but the shape of the roof design should be considered. Roof with wide eaves affected in improving the thermal performance of the building.

2) Relationship Performance and Comfort by Wall and Opening (Percentage WWR)

The relationship of performance and comfort with walls and openings (percentage WWR) is shown in the following graph (Figure 4). Referring to the theory of the openings associated with the thermal performance which states that the percentage of WWR appropriate (not too wide and not too small) will be more effective and gives a better effect on the thermal performance of buildings evident in this analysis. This is indicated by WWR $28.57 \%$ had the most excellent thermal performance. And on the discussion of thermal properties earlier stated that the aluminum material on the frame has the potential to contribute to the thermal was also apparent in this analysis. This is indicated by a poor performance on the numbers 3,4 , and 9 in the scatter graph. 


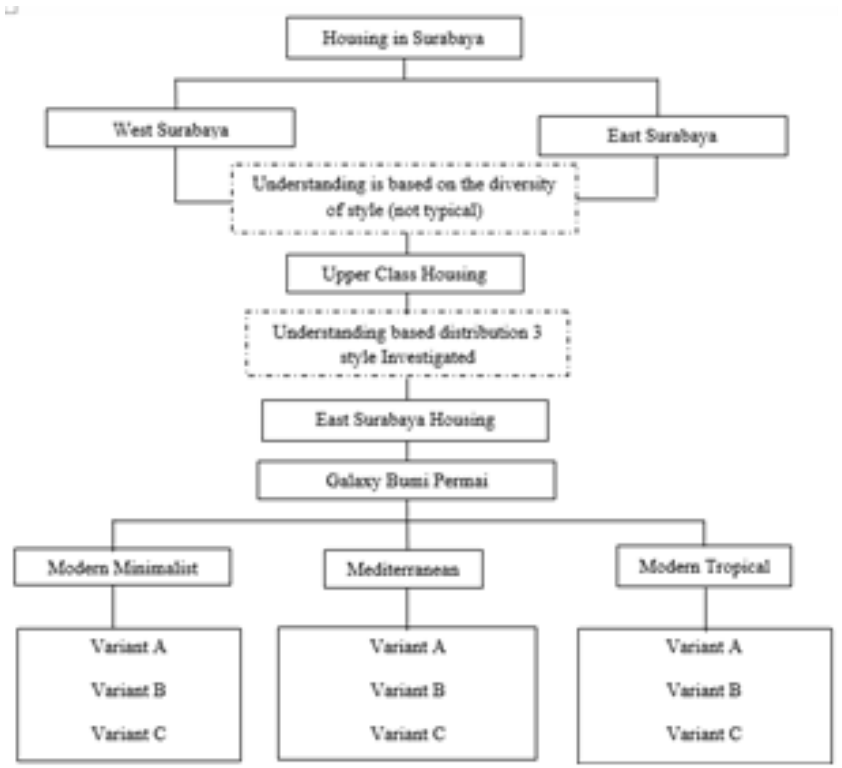

Figure 1. Flowchart understanding population and sample

TABLE 1.

TOP CRITERIA (KEY ELEMENTS) MUST BE THERE IN EACH STYLE.

\begin{tabular}{ll}
\hline \hline \multicolumn{1}{c}{ Style } & \multicolumn{1}{c}{ Main Characteristics } \\
\hline Modern & $\begin{array}{l}\text { The walls are plain, minimal ornaments / } \\
\text { decorations [9] }\end{array}$ \\
Medimalist & $\begin{array}{l}\text { Has a veranda with a roof shaped canopy } \\
\text { leaning on the wall and is supported by pillars } \\
\text { (portico) (an adaptation of the climate in the } \\
\text { country of origin) [10] } \\
\text { Modern Tropical }\end{array}$ \\
\hline \hline
\end{tabular}

TABLE 2

PRESENTAGE DISTRIBUTION OF COMPLIANCE ELEMENTS ON EACH STYLE.

\begin{tabular}{lccccc}
\hline \hline & Roof & Wall & Opening & Ornament & $\begin{array}{c}\text { Sun } \\
\text { Shading }\end{array}$ \\
\cline { 2 - 6 } & $\%$ & $\%$ & $\%$ & $\%$ & $\%$ \\
\hline $\begin{array}{l}\text { Modern } \\
\text { Minimalist }\end{array}$ & 10 & 70 & 10 & 5 & 5 \\
$\begin{array}{l}\text { Mediterranean } \\
\text { Modern }\end{array}$ & 5 & 10 & 5 & 10 & 70 \\
Tropical & 70 & 5 & 10 & 5 & 10 \\
\hline \hline
\end{tabular}

TABLE 3. DETERMINATION OF VARIANT EACH STYLE.

\begin{tabular}{lccccccc}
\hline \hline & & \multicolumn{5}{c}{ Aspect } & \\
\cline { 3 - 6 } \multicolumn{1}{c}{ Style } & Hou & Roo & Wal & Open & Ornam & Sun & Vari \\
& se & f & 1 & ing & ent & Shadi & ant \\
& & $(10$ & $(70$ & $(10 \%$ & $(5 \%)$ & ng & \\
& & $\%)$ & $\%)$ & ) & & $(5 \%)$ & \\
\hline Ex & 1 & & & & & \\
Moder & 2 & & & & & \\
$n$ & $n$ & $n$ & & & & & \\
Minim & & & & & & \\
alist & & & & & & \\
\hline \hline
\end{tabular}

3) Relationship Performance and Comfort by Sun Shading Design

The relationship of performance and comfort with sun shading design shown in the graph below (Figure 5). Referring to previous discussions on the thermal performance related to sun shading design on humid tropical house stated that the addition of shading or sun canopy on windows / openings is highly recommended to help achieve thermal comfort which is one indicator of good thermal performance. This is consistent with the results of this analysis. In addition to the canopy in each
TABLE 4.

EACH SAMPLE HOUSE SYLE

\begin{tabular}{|c|c|c|c|}
\hline Sample & $\begin{array}{c}\text { Modern } \\
\text { Minimalist }\end{array}$ & Mediterranean & $\begin{array}{l}\text { Modern } \\
\text { Tropical }\end{array}$ \\
\hline Variant A & & & \\
\hline Variant B & & & \\
\hline Variant $\mathrm{C}$ & & & \\
\hline
\end{tabular}

TABLE 5.

MODELING 9 SAMPLE HOUSE

\begin{tabular}{|c|c|c|c|}
\hline & Variant A & Variant B & Variant C \\
\hline $\begin{array}{c}\text { Moden } \\
\text { Minimalist }\end{array}$ & & & \\
\hline
\end{tabular}

window is highly recommended, sun shading with portico forms can also be adapted and added.

\section{CONCLUSION}

The explanation of table and the graph above is as follows:

A. The thermal performance inside the building which is designed with the three enveloping style

From the overall analysis with several indicators as the filter order which is time and comfort duration, degree hours, and percent dissatisfaction, modern minimalist 
style B variant is the style that has the best thermal performance compared to the other variants. This is shown by the comfort duration being no less than 14 hours, degree hours being $107,2 \mathrm{Kh}$ and percent dissatisfaction being $100 \%$.

TABLE 6.

THE RESULTS OF THE SIMULATIONS OF THE NINE HOUSE

\begin{tabular}{|c|c|c|c|c|c|c|c|c|c|c|c|}
\hline \multirow{4}{*}{ Style } & \multirow{4}{*}{ Variant } & \multicolumn{10}{|c|}{ Simulation data } \\
\hline & & \multicolumn{5}{|c|}{ Time and Comfort Duration } & \multicolumn{4}{|c|}{ Degree Hours } & \multirow{3}{*}{$\begin{array}{c}\text { Percent } \\
\text { Dissatisfaction }\end{array}$} \\
\hline & & \multirow[b]{2}{*}{ Time } & \multirow[b]{2}{*}{$\begin{array}{c}\text { Comfort } \\
\text { Duration } \\
\text { (hours) }\end{array}$} & \multirow[b]{2}{*}{$\begin{array}{c}\text { Comfort } \\
\text { Duration }+ \\
\text { Comfort } \\
\text { Standard }\end{array}$} & \multicolumn{2}{|c|}{ Overheated } & \multirow[b]{2}{*}{$\begin{array}{l}\text { Indoor } \\
(\mathrm{Kh})\end{array}$} & \multirow[b]{2}{*}{$\begin{array}{c}\text { Duration } \\
\text { (hours) }\end{array}$} & \multirow[b]{2}{*}{$\begin{array}{l}\text { Outdoor } \\
\text { (Kh) }\end{array}$} & \multirow[b]{2}{*}{$\begin{array}{c}\begin{array}{c}\text { Duration } \\
\text { (hours) }\end{array}\end{array}$} & \\
\hline & & & & & Duration & $\begin{array}{l}\text { Time } \\
\text { (hours) }\end{array}$ & & & & & \\
\hline \multirow{3}{*}{$\begin{array}{l}\text { Minimalis } \\
\text { Modern }\end{array}$} & A & $18.00-11.00$ & 7 & - & $00.00-00.00$ & 24 & 98,3 & 24 & 20,6 & 22 & $100 \%$ \\
\hline & B & $18.00-09.00$ & 14 & - & $00.00-00.00$ & 24 & 107,2 & 24 & 20,6 & 22 & $100 \%$ \\
\hline & $\mathrm{C}$ & $00.00-00.00$ & - & - & $00.00-00.00$ & 24 & 113,9 & 24 & 20,6 & 22 & $100 \%$ \\
\hline \multirow{3}{*}{ Mediterania } & $\mathrm{A}$ & $21.00-13.00$ & 8 & - & $00.00-00.00$ & 24 & 84,1 & 24 & 20,6 & 22 & $98 \%$ \\
\hline & $\mathrm{B}$ & $19.00-10.30$ & 8,5 & - & $00.00-00.00$ & 24 & 125 & 24 & 20,6 & 22 & $96 \%$ \\
\hline & $\mathrm{C}$ & $00.00-00.00$ & - & - & $00.00-00.00$ & 24 & 105 & 24 & 20,6 & 22 & $97 \%$ \\
\hline \multirow{3}{*}{$\begin{array}{c}\text { Tropis } \\
\text { Modern }\end{array}$} & $\mathrm{A}$ & $17.00-11.00$ & 6 & - & $00.00-00.00$ & 24 & 151,4 & 24 & 20,6 & 22 & $31 \%$ \\
\hline & $\mathrm{B}$ & $15.00-18.30$ & 7 & - & $00.00-00.00$ & 24 & 321 & 24 & 20,6 & 22 & $100 \%$ \\
\hline & $\mathrm{C}$ & $15.00-13.00$ & 3 & - & $00.00-00.00$ & 24 & 137,1 & 24 & 20,6 & 22 & $97,90 \%$ \\
\hline
\end{tabular}

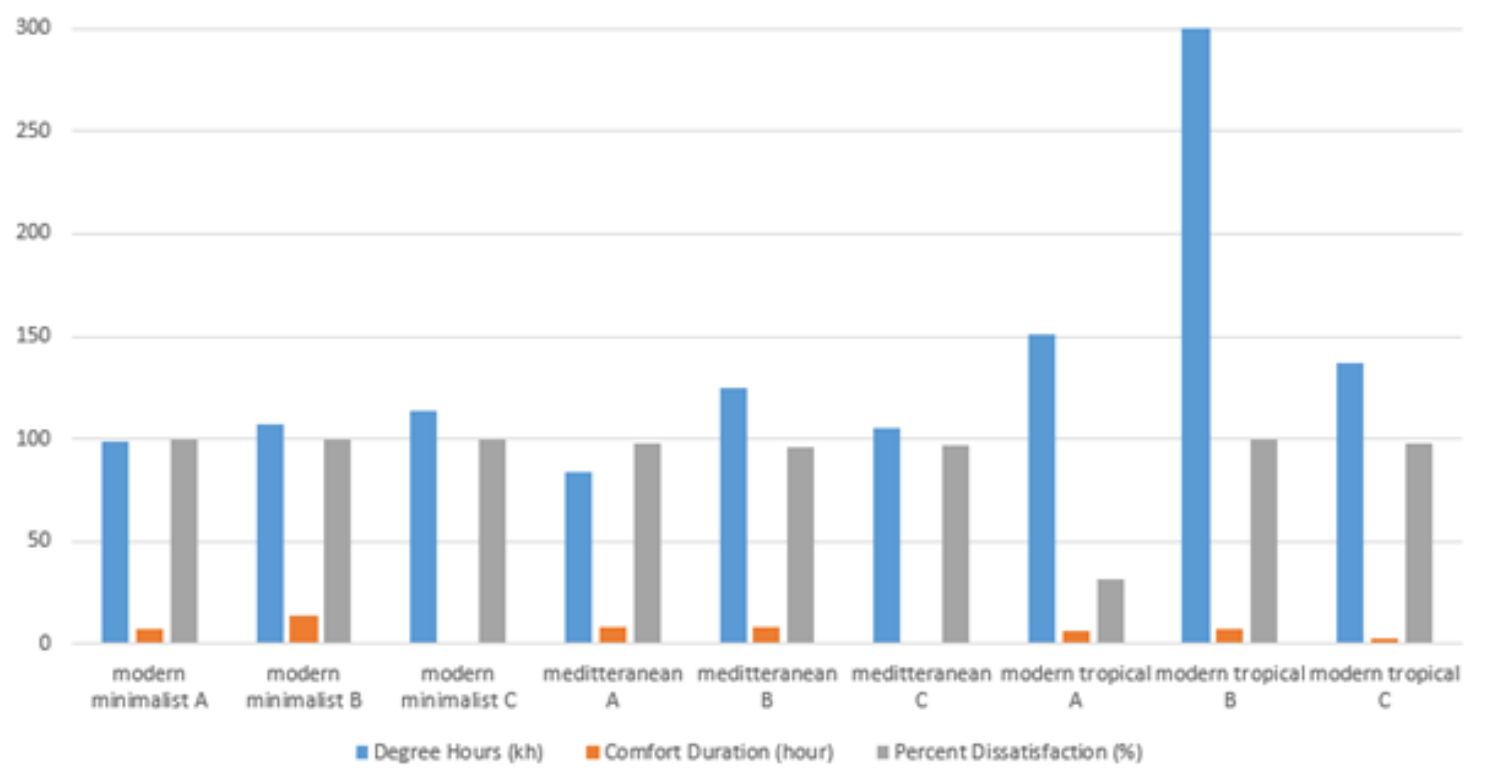

Figure. 2. The Comparison of The Overall Simulation Result.

B. The effect of the enveloping design and the elements towards the thermal conditions inside the building

In the overall simulation results, it is mentioned that the envelope side which contribute sto most of the heat generation is the side which consists of wall element and not the fixed windows with a wide dimension. On the contrary, the envelope side which generates the least heat is the side which consists of the wall element, opening (windows), door and sun shading.

The following is the summary of the analysis of the relation between performance and the design along with the elements:

a. The roof material does not have any significant influence whereas roof shape has influence on the thermal conditions. Typical tropical roof design with a wide terrace has the best performance. This matches with the theory and concepts of housing in humid tropical climate area which has been explained previously.

b. Wall configuration and opening with the WWR percentage of $28,57 \%$ with the wood frame material has the best performance.

c. Sun shading design in the form of terrace and canopied balcony (portico) as well as the canopy on each window is the sun shading with the best performance.

C. The potential style that can be applied in humid tropical climate areas

Modern minimalist B variant and Mediterranean B variant show the best results compared to the other styles and the two has only a slight difference. Both styles can be applied in a humid tropical climate. B variant is the house sample which has several modifications on the elements but the original style characteristic still remain apparent so that this is not only of a good quality but also suitable in terms of design and climate adjustment. 
TABLE 7.

THE HOTTEST ENVELOPE SIDE ON EACH SAMPLES

\begin{tabular}{|c|c|c|c|c|}
\hline Style & $\begin{array}{l}\text { Envelope side heat } \\
\text { contributor }\end{array}$ & Variant A & Variant B & Variant $\mathrm{C}$ \\
\hline \multirow[b]{2}{*}{ Modern Minimalist } & Highest & $\begin{array}{l}\text { Top right }\left(2^{\text {nd }} \text { floor }\right)-\text { envelope } \\
\text { of bedroom } 1\end{array}$ & $\begin{array}{c}\text { Left }\left(1^{\text {st }} \text { floor }\right)-\text { envelope of } \\
\text { garage }\end{array}$ & $\begin{array}{c}\left.\text { Corner ( } 2^{\text {nd }} \text { floor }\right) \text { - envelope } \\
\text { of bedroom } 1\end{array}$ \\
\hline & Lowest & $\begin{array}{c}\text { Under ( } 1^{\text {st }} \text { floor) (double } \\
\text { fasade) - envelope of living } \\
\text { room }\end{array}$ & $\begin{array}{c}\text { Middle }\left(1^{\text {st }} \text { floor }\right) \text { - envelope } \\
\text { of terrace }\end{array}$ & (a) \\
\hline \multirow{2}{*}{ Mediterranean } & Highest & Roof & $\begin{array}{l}\left.\text { Left ( } 1^{\text {st }} \text { floor }\right) \text { - envelope of } \\
\text { master bedroom }\end{array}$ & $\begin{array}{l}\left.\text { Right ( } 2^{\text {nd }} \text { floor }\right) \text { - envelope } \\
\text { of bedroom } 1\end{array}$ \\
\hline & Lowest & $\begin{array}{c}\left.\text { Middle ( } 1^{\text {st }} \text { floor }\right) \text { - envelope of } \\
\text { terrace }\end{array}$ & $\begin{array}{c}\text { Corner }\left(2^{\text {nd }} \text { floor }\right) \text { - envelope } \\
\text { of balcony }\end{array}$ & $\begin{array}{l}\text { Left }\left(2^{\text {nd }} \text { floor }\right) \text { - envelope of } \\
\text { bedroom } 2\end{array}$ \\
\hline \multirow{2}{*}{ Modern Tropical } & Highest & $\begin{array}{c}\text { Corner }\left(2^{\text {nd }} \text { floor }\right)-\text { envelope } \\
\text { of lounge }\end{array}$ & $\begin{array}{l}\left.\text { Left ( } 1^{\text {st }} \text { floor }\right)- \text { envelope of } \\
\text { garage }\end{array}$ & $\begin{array}{l}\left.\text { Left ( } 1^{\text {st }} \text { floor }\right) \text { - envelope of } \\
\text { guest bedroom }\end{array}$ \\
\hline & Lowest & $\begin{array}{c}\left.\text { Under ( } 1^{\text {st }} \text { floor }\right) \text { envelope of } \\
\text { living room }\end{array}$ & $\begin{array}{c}\text { Right }\left(1^{\text {st }} \text { floor }\right)-\text { envelope } \\
\text { of terrace }\end{array}$ & $\begin{array}{c}\text { Middle }\left(1^{\text {st }} \text { floor }\right) \text { - envelope } \\
\text { of terrace }\end{array}$ \\
\hline
\end{tabular}

TABLE 8.

COMPOSERS ENVELOPE SIDE ELEMENT WHICH GAVE HEAT CONTRIBUTOR ON EACH SAMPLES

\begin{tabular}{cccc}
\hline \hline Style & Envelope Side Element & Variant A & Variant B \\
\cline { 2 - 4 } Modern Minimalist & Highest & Wall, fixed window & Wall, garage door \\
& Lowest & $\begin{array}{c}\text { wall, window, door, and } \\
\text { sun shading (double facade } \\
\text { wall) }\end{array}$ & $\begin{array}{c}\text { Wall, window, door, sun } \\
\text { shading (canopy) }\end{array}$ \\
\hline \multirow{2}{*}{ Mediterranean } & Highest & Roof & Wall, window \\
\cline { 2 - 4 } Modern Tropical & Lowest & $\begin{array}{c}\text { wall, window, door, sun } \\
\text { shading (canopy) }\end{array}$ & $\begin{array}{c}\text { Wall, window, door, sun } \\
\text { shading (canopy) }\end{array}$ \\
\cline { 2 - 4 } & Highest & Wall, fixed window & Wall, garage door \\
& Lowest & Wall, ventilation hole & Wall, window \\
\hline \hline
\end{tabular}

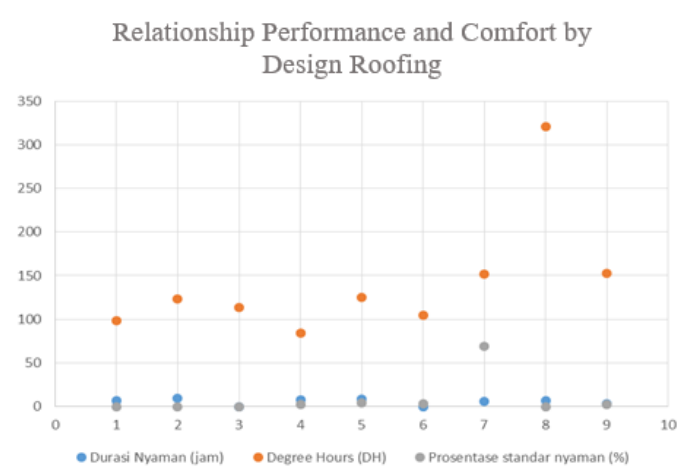

Annotation

1 : Flat roof-Concrete (modern minimalist A)

2 : Hipped roof. Eaves - clay tile (modern minimalist B)

3 : Hipped roof. No eaves - clay tile (modern minimalis C)

4 : Hipped roof. Deep eaves - clay tile (mediterranean A)

5 : Hipped roof. Deep eaves - clay tile (mediterranean B)

6 : Hipped roof. Deep eaves - clay tile (mediterranean C)

7 : Typical tropical. Wide eaves - clay tile (modern tropical A)

8: Typical tropical. Narrow eaves - clay tile (modern tropical B)

9 : hipped roof. Wide eaves - clay tile (modern tropical C)

Figure. 3. Relationship Performance and Comfort by Design Roofing

Relationship Performance and Comfort by Wall and Opening (Percentage WWR)

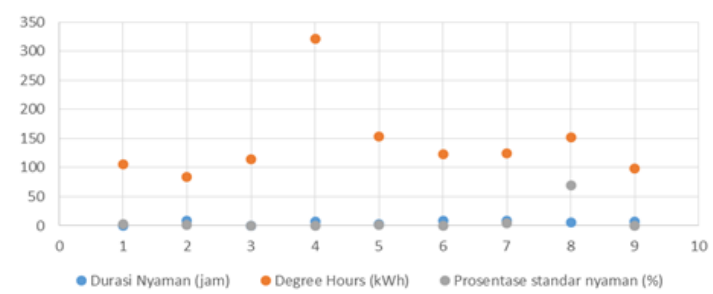

Figure. 4. Relationship Performance and Comfort by Wall and Opening (Percentage WWR)

Relationship Performance and Comfort by Sun Shading Design

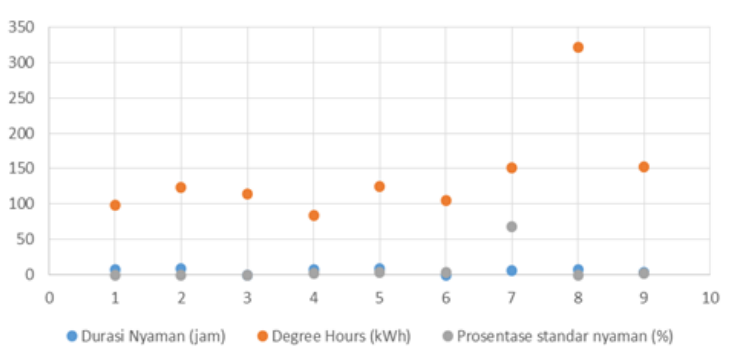

Annotation:

1: $10 \%$ - wood frame (mediterranean C)

$2: 15,47 \%$ - wood frame (mediterranean A)

$3: 16,67 \%$-alumunium frame (modern minimalist $\mathrm{C}$ )

$4: 17,86 \%$ - alumunium frame (modern tropical B)

$5: 17,86 \%$ - wood frame (modern tropical C)

$6: 18,45 \%$ - wood frame (modern minimalist $B$ )

$7: 20,23 \%$ - wood frame (mediterranean B)

$8: 28,57 \%$ - wood frame (modern tropical A)

$9: 58.3 \%$ - alumunium frame (modern minimalist $\mathrm{A}$ )

Figure. 5. Relationship Performance and Comfort by Sun Shading Design. 


\section{ACKNOWLEDGEMENT}

This research was supported/partially supported by environmental architecture department of ITS Surabaya. We thank our colleagues from environmental architecture department of ITS Surabaya who provided insight and expertise that greatly assisted the research, although they may not agree with all of the interpretations/conclusions of this paper.

\section{REFERENCES}

[1] Reliantoro, Sigit, "The Gold for Green", 1st ed, East Jakarta: Kementrian Lingkungan Hidup, 2012

[2] Dewan Pengurus Lembaga Pengembangan Jasa Konstruksi Nasional, "Peraturan Lembaga Pengembangan Jasa Konstruksi“, 2007
[3] Prijotomo, Josef, "Pasang Surut Arsitektur Indonesia", Surabaya: Wastu Lanas Grafika, 2008

[4] Lechner, Norbert, "Heating, Cooling, Lighting", Canada: John Wiley \& Sons Inc, 2001

[5] Evans, M, "Housing, climate, and comfort", London: Architectural Press London, 1980

[6] Anastasia, Njo. (2013). "Peta Persepsi Konsumen Terhadap Atribut Rumah Tinggal di Surabaya”, Jurnal Manajemen dan Kewirausahaan, Vol. 15, No. 2, pp. 141-152.

[7] Margono, S, "Metodologi Penelitian Pendidikan", Jakarta: Rineka Cipta, 2004

[8] Moneo, Raffael. “On Typology”, Oppositions 13, The MIT Press, Macashusette, 1979, pp. 23-45.

[9] Bertoni, Franco, "Minimalist Architecture", Italia: Dogi Spa, 2004

[10] Newcomb, Rexford, "Mediterranean Domestic Architecture for The United States, New York: Hawthrone Printing Company, 1992

[11] Utami, Rahminindari. "Pengaruh Elemen Bangunan Terhadap kenyamanan Termal Penghuni Bagi Rumah Kolonial di Kalianget" 